\title{
Assessment of bio-agent (Trichoderma Harzianum) in the management of two pepper varieties infected with root-knot nematode (Meloidogyne Incognita)
}

\author{
N. B. IZUOGU, H. S. BABA, \\ E. O. WINJOBI \\ Crop Protection Department, Faculty of Agriculture, University of Ilorin, Nigeria \\ ${ }^{*}$ Corresponding author: nkbetsyizuogu@ gmail.com
}

Manuscript received December 20, 2018; revised January 23, 2019; Accepted January 30, 2019

\begin{abstract}
Two field trials were carried out at the Teaching and Research Farm of the University of Ilorin in the 2012 and 2014 planting seasons to find out the effeciency of Trichoderma harzianum as a bio-control agent in controlling root-knot nematode (Meloidogyne incognita) in two pepper varieties (F1 Nikita and Gianfranco Fuscello). A $2 \times 2$ factorial design fitted into a randomized complete block design (RCBD) was used with 5 replications. The $T$. harzianum filtrate significantly increased plant height, number of leaves, and yield. The control showed higher root galling and soil nematode population. Varietal differences showed that F1 Nikita performed significantly better than G. Fuscello. The combination of Trichoderma and F1 Nikita appears effective for managing root-knot nematodes.
\end{abstract} tolerant

Keywords: F1 Nikita, Gianfranco Fuscello, bio-pesticides, nematology, susceptible,

\section{Introduction}

Pepper, capsicum, is one of the genus from flowering plants in the nightshade family, Solanaceae. Its species originated from the Americans. Some species of capsicum are used as spices, medicines, or vegetables. Depending on the place and type, the fruits of capsicum plants have a variety of names. They are often referred to as hot chilli pepper, or sweet pepper in Britain, red or green pepper and just capsicum in Australia, India, and New Zealand. Pepper is the world's second most important vegetable, ranking after tomato. Pepper is an essential agricultural product not because of its economic importance alone but also due to its medicinal and nutritional value; it is also a very good natural source 
of colour and antioxidants [1]. It is the most cultivated type of flavouring spice and food colouring, and it provides essential vitamins and minerals [2]. Both hot and sweet pepper contain larger amounts of vitamin $C$ to prevent cold than any other vegetable [3]. Pepper is also used in the production of cosmetics, condiments, and medicine and functions as ornamental in gardens [4].

There are different pests and diseases which attack sweet pepper. The pests include aphids, cutworms, flea beetles, and hornworms, while the diseases are rot, blossom, anthracnose, tobacco mosaic virus, bacterial spot, mildew, and nematode diseases [5].

Root-knot nematodes are insidious, reduce yield and are silent enemies of most food, horticultural, vegetable, and fibre crops [6]. Indirect damages from nematodes of crop plants include their role in the plant disease complex by making plant roots more susceptible to secondary infection by fungi and bacteria and their role as vectors of many viruses [7], [8].

Nematode management is a practice of maintaining plant parasitic nematode below the economic threshold level, using chemical and non-chemical methods. The chemical method has been primarily used as the standard to achieve nematode control, but its hazardous and adverse effects on man and his biotic environment, phytotoxicity in plants, contaminations of water, and other forms of pollution have stimulated great interest in the search for alternative management methods.

Bio-pesticides possess a spectrum of properties from pesticidal to antimicrobial activities against pathogens. They are cheaper and more benign. In recent times, the use of bio-pesticides of microbial origin has been fast gaining ground in addressing the challenges posed by plant parasitic nematodes. Trichoderma species are fungi residing in almost all agricultural soils and are said to have more beneficial qualities. T. virens have been employed in the protection of cotton seedlings Phythium ultinum [9]. The metabolites secreted by some Trichoderma species exhibit fungistatic effects on the growth of Ceratocytis paradoxa [10]. There is a dearth of information on the bio-activity of Trichoderma against root-knot nematode infecting pepper.

Hence, the objectives of this study were to investigate the efficacy of Trichoderma harzianum against root-knot nematode, determine the effect of treatment on the growth and yield of the two pepper varieties, and evaluate the resistance or susceptibility of the crop to root-knot nematode.

\section{Materials and methods}

The experimental trial was performed at the University of Ilorin, Teaching and Research Farm in the 2012 and 2014 planting seasons. 


\section{Sources of root-knot nematode}

The root-knot nematode was obtained from heavily galled roots of Celosia argentea collected from the Lao area of Airport Road, Ilorin. The root-knot nematode had been previously identified at the International Institute of Tropical Agriculture (IITA) as Meloidogyne incognita Race 2. The roots weighing about $100 \mathrm{~kg}$ were carefully washed to remove soil particles and cut into pieces with knife before incorporating evenly into the experimental field of $100 \times 4 \mathrm{~m}^{2}$ size. There was a two-metre alley between the two main plots.

\section{Sources of sweet pepper and Trichoderma harzianum}

The hybrid seeds were obtained at an agro-shop located at Mokola, Ibadan. Culture of filtrate T. harzianum was obtained at the Ladoke Akintola University of Technology (LAUTECH), Ogbomoso, Oyo State, Nigeria. Thirty millilitres (30 ml) of T. harzianum was mixed with 15 litres of water and applied to the treated plots one week after the transplanting of seedlings.

\section{Raising of nursery}

Pepper seeds were planted at a depth of about $1.5 \mathrm{~cm}$ in nursery trays. Germination took place between 6 and 10 days. Seedlings were ready for transplanting at three weeks after planting.

\section{Soil nematode sampling and identification}

Twenty soil samples were randomly collected in a zig-zig pattern from each plot for initial soil nematode population and identification. Using the method of extraction as described by [11], the nematodes were extracted and counted, and identification was confirmed at the International Institute of Tropical Agriculture (IITA) in Ibadan.

\section{Field layout and transplanting of pepper seedlings}

The sandy loam experimental field was ploughed, harrowed, and formed into ridges. The field was divided into two main plots, each measuring $50 \times 4 \mathrm{~m}$ $\left(200 \mathrm{~m}^{2}\right)$. While one plot served as the control plot, the other served as the treated plot. Each main plot was divided into five blocks, and a block consisted of subplots, each containing 5 ridges with 0.5 spacing between the ridges. The chopped galled roots of Celosia argentea were incorporated equally into the two main plots to increase the initial soil nematode population in the soil. The 
experimental design was a $2 \times 2$ factorial design fitted into a randomized complete block design model (RCBD) and replicated five times. Pre-emergence herbicides (Paraquat and Glyphosate) were applied to the experimental plots one week before transplanting. After the transplanting of seedlings, subsequent weeding at three weeks and six weeks was done manually.

\section{Data collection}

The recorded parameters were plant height, number of leaves and fruits per plant, root gall index, and initial and final soil nematode population.

\section{Data analysis}

All numerical data obtained were subjected to analysis of variance, and means were separated using Duncan's multiple range test (DMRT) at $p=0.5$

\section{Results and discussion}

Following the similar trends observed in the two years' trials, the results were pooled together. The statistical analysis revealed that all the Trichodermatreated plants performed significantly higher $(p=0.5)$ than the control plants with respect to growth (height and number of leaves) and yield (number of fruits) as well as reduction of root galls and soil nematode population (tables 1-3). Though both varieties were susceptible to root-knot nematode infection, there were significant differences between them, especially in yield. F1 Nikita performed significantly higher than $G$. Fuscello in all the parameters measured. F1 Nikita in the presence of Trichoderma harzianum showed higher tolerance to nematode infection.

The findings in the present study have revealed the antagonistic and suppressive ability of the fungus against root-knot nematode by disabling them from multiplication that otherwise would have reduced yield as was evident in the control plot. Bio-control agents have been reported to improve the health of plants due to the control of seedling diseases [12] and thus contribute to overall productivity. They also exhibit self-propagation under unfavourable conditions and may thus remain in the soil for long [13]. Many findings suggest that Trichoderma harzianum strains strongly affect plant development and biochemistry. They have been reported to increase plant nutrient uptake and fertilizer utilization [14] to grow more quickly and improve plants' greenness, which may result in higher synthetic rates. [15] reported Trichoderma species to play a significant role as plant-promoting microorganism. It had also been reported that Trichoderma species found in close contact with roots contributed 
to plant growth [14]. However, it is still not confirmed if the benefits derived from Trichoderma occur because they directly attack and control disease-causing nematode or because they have direct effect upon plants. [6] reported inhibitions in most fungal plant pathogens by substances produced by Trichoderma spp. and suggested that controlling other soil-borne pathogenic fungi Trichoderma harzianum will further provide a better, enabling environment where plants will develop more vigorously without being suppressed by other microorganisms, which would otherwise affect or make it vulnerable to secondary infections pioneered by plant-parasitic nematodes. The study further revealed that, though the two pepper varieties were susceptible to root-knot nematode infection, varietal differences played a significant role in their performance. From the results obtained, F1 Nikita expressed its superiority in yield and nematode tolerance over G. Fuscello under Trichoderma harzianum treatment. The combination of F1 Nikita and T. harzianum in a nematode-infested field is therefore desirable.

\section{Conclusions}

Trichoderma harzianum proved effective and could be employed as a bioagent against root-knot nematode. Increasing the naturally existing T. harzianum would be beneficial to farmers. Plant pathologists should isolate these organisms and culture them for farmers' use. Hybrid pepper variety F1 Nikita should be released to pepper farmers, especially those in zones that are endemic to nematodes.

Table 1. Effect of $T$. harzianum on the plant height of two sweet pepper varieties inoculated with root-knot nematode

\begin{tabular}{lccccc}
\hline \multicolumn{1}{c}{ Treatment } & 5WAP* & 6WAP & 7WAP & 8WAP & 9WAP \\
\hline F1 Nikita (Trichoderma) & $9.1 \mathrm{a}$ & $9.7 \mathrm{a}$ & $10.1 \mathrm{a}$ & $10.1 \mathrm{a}$ & $10.7 \mathrm{a}$ \\
F1 Nikita (No Trichoderma) & $3.1 \mathrm{c}$ & $3.5 \mathrm{c}$ & $4.6 \mathrm{c}$ & $5.9 \mathrm{c}$ & $6.2 \mathrm{c}$ \\
G. fuscello (Trichoderma) & $4.9 \mathrm{~b}$ & $5.3 \mathrm{~b}$ & $6.5 \mathrm{~b}$ & $6.9 \mathrm{~b}$ & $7.1 \mathrm{~b}$ \\
G. fuscello (No Trichoderma) & $3.3 \mathrm{c}$ & $3.6 \mathrm{c}$ & $4.1 \mathrm{c}$ & $5.5 \mathrm{c}$ & $5.6 \mathrm{c}$ \\
SED & 0.24 & 0.26 & 0.45 & 0.38 & 0.35 \\
Level of significance & $\mathrm{S}$ & $\mathrm{S}$ & $\mathrm{S}$ & $\mathrm{S}$ & $\mathrm{S}$ \\
\hline WAP* - weeks after planting & & & & &
\end{tabular}

Means within the same column followed by the same letter(s) do not differ significantly at $\mathrm{p}=0.5$ according to Duncan's multiple range test. 
Table 2. Effect of T. harzianum on the number of leaves of two sweet pepper varieties inoculated with root-knot nematode

\begin{tabular}{lccccc}
\hline \multicolumn{1}{c}{ Treatment } & 5WAP* & 6WAP & 7WAP & 8WAP & 9WAP \\
\hline F1 Nikita (Trichoderma) & $15.6 \mathrm{a}$ & $16.8 \mathrm{a}$ & $18.4 \mathrm{a}$ & $19.8 \mathrm{a}$ & $20.6 \mathrm{a}$ \\
F1 Nikita (No Trichoderma) & $5.0 \mathrm{c}$ & $6.0 \mathrm{c}$ & $8.6 \mathrm{c}$ & $10.0 \mathrm{c}$ & $10.7 \mathrm{c}$ \\
G. fuscello (Trichoderma) & $8.2 \mathrm{~b}$ & $10.0 \mathrm{~b}$ & $11.6 \mathrm{~b}$ & $12.8 \mathrm{~b}$ & $14.0 \mathrm{~b}$ \\
G. fuscello (No Trichoderma) & $4.4 \mathrm{c}$ & $5.2 \mathrm{c}$ & $7.2 \mathrm{c}$ & $7.6 \mathrm{~d}$ & $8.0 \mathrm{~d}$ \\
SED & 0.42 & 0.66 & 0.75 & 0.52 & 0.55 \\
Level of significance & $\mathrm{S}$ & $\mathrm{S}$ & $\mathrm{S}$ & $\mathrm{S}$ & $\mathrm{S}$ \\
\hline
\end{tabular}

WAP* - weeks after planting

Means within the same column followed by the same letter(s) do not differ significantly at $\mathrm{p}=0.5$ according to Duncan's multiple range test.

Table 3. Effect of T. harzianum on the mean number of fruits per plant, root gall index, and soil nematode populations

\begin{tabular}{lcccc}
\hline \multicolumn{1}{c}{ Treatment } & $\begin{array}{c}\text { Mean fruit } \\
\text { no/plant }\end{array}$ & $\begin{array}{c}\text { Root gall } \\
\text { index }\end{array}$ & \multicolumn{2}{c}{ Soil nematode population } \\
\cline { 5 - 6 } F1 Nikita (Trichoderma) & $26.0 \mathrm{a}$ & $0.98 \mathrm{a}$ & $155 \mathrm{~b}$ & $53.0 \mathrm{a}$ \\
F1 Nikita (No Trichoderma) & $19.8 \mathrm{~b}$ & $2.04 \mathrm{c}$ & $146 \mathrm{a}$ & $348.0 \mathrm{c}$ \\
G. fuscello (Trichoderma) & $23.4 \mathrm{a}$ & $1.52 \mathrm{~b}$ & $168 \mathrm{c}$ & $74.93 \mathrm{~b}$ \\
G. fuscello (No Trichoderma) & $16.8 \mathrm{c}$ & $2.66 \mathrm{~d}$ & $159 \mathrm{~b}$ & $376.00 \mathrm{~d}$ \\
SE & 0.59 & 0.05 & 0.54 & 26.69 \\
\hline
\end{tabular}

Means within the same column followed by the same letter(s) do not differ significantly at $\mathrm{p}=0.5$ according to Duncan's multiple range test.

\section{References}

[1] Howard, L. R., Talcott, S. T., Brenes, C. H., Villalon, B. (2000), Changes in phytochemical and antioxidant activity of selected pepper cultivars (Capsicum sp.) as influenced by maturity. Journal of Agriculture and Food Chemistry 48(5), 1713-1720.

[2] Sanusi, M. M., Ayinde, I. A. (2013), Profitability of pepper production in derived Savannah zone of Ogun State. IJAFS 4(2), 401-410.

[3] Bosland, P. W., Votava, E. J. (2000), Pepper vegetable and spice, capsicum. New York: CABI Publishing. 1-10.

[4] Rubatzky, V., Yomaguchi, M. (1997), World vegetables. $2^{\text {nd }}$ edition. USA: International Thomson Publishing. 553-562.

[5] Schippers, R. R. (2000), African indigenous vegetables. An overview of the cultivated species. Chatham, U.K., NRI, CTA, DFID. 
[6] Izuogu, N. B., Abiri, T. O. (2015), Efficacy of Trichoderma harzianum $\mathrm{T}_{22}$ as a bio-control agent against root-knot nematode (Meloidogyne incognita) on some soybean varieties. Croat. J. Food Sci. Technol. 7(2), 47-51.

[7] Archana, N. Singh, Prasad, D. (2014), Management of plant parasitic nematodes by the use of botanicals. J. Plant Physiol. Pathol. 2(1). DOI:10.4172/2329-955X.1000116.

[8] Izuogu, N. B. (2013), Seasonal abundance and distribution of nematode pests of Musa sp. in Ilorin, Kwara State, Nigeria. Aspects of Applied Biology 120, 77-83.

[9] Howell, C. R., Stipanovic, R. D. (1993), Suppression of Gliocladium virens phytotoxin production with steroid inhibitors. Available at: www.freepatentsonline.com/5268173.html.

[10] Eziashi, E. I., Uma, N. U., Adekunle, A. A., Airede, C. E. (2006), Effect of metabolites produced by Trichoderma species against Ceratocytis paradoxa in culture medium. African Journal of Biotechnology 5(9), 703-706.

[11] Whitehead, A. G., Hemming, J. R. (1965), A comparison of some quantitative methods of extracting small vermiform nematodes from soil. Annals of Applied Biology 55, 25-38.

[12] Howell, C. R. (1998), The roles of antibiosis in bio-control. In: Harman G. E., Kubiek, C. P. (eds.), Trichoderma and Giliocladium 2: 173-184.

[13] Sharma, P., Pandey, R. (2009) Biological control of root-knot nematode, Meloidogyne incognita in the medicinal plant: Withania sominifera and the effects of bio-control agents on plant growth. African Journal of Agriculture Research 4(6), 564-567.

[14] Harman, G. E. (2000), The myths and dogmas of biocontrol changes in perception derived from research on Trichoderma harzianum strain T $\neg 22$. Plant Disease 84(4), 377-393.

[15] Sharon, E., Spiegel Y., Solomon, R., Curtis, R. H. C. (2002), Characterization of Meloidogyne javanica surface coat with antibodies and their effect on nematode behaviour. Parasitology 125, 177-185. 